University of Nebraska - Lincoln

DigitalCommons@University of Nebraska - Lincoln

2003

\title{
Language Basis of Reading Disabilities and Implications for Early Identification and Remediation
}

Hugh W. Catts

University of Kansas, catts@ku.edu

Tiffany Hogan

University of Nebraska - Lincoln, thogan2@unl.edu

Follow this and additional works at: https://digitalcommons.unl.edu/specedfacpub

Part of the Special Education and Teaching Commons

Catts, Hugh W. and Hogan, Tiffany, "Language Basis of Reading Disabilities and Implications for Early Identification and Remediation" (2003). Special Education and Communication Disorders Faculty Publications. 36.

https://digitalcommons.unl.edu/specedfacpub/36

This Article is brought to you for free and open access by the Department of Special Education and Communication Disorders at DigitalCommons@University of Nebraska - Lincoln. It has been accepted for inclusion in Special Education and Communication Disorders Faculty Publications by an authorized administrator of DigitalCommons@University of Nebraska - Lincoln. 


\title{
Language Basis of Reading Disabilities and Implications for Early Identification and Remediation
}

\author{
Hugh W. Catts and Tiffany P. Hogan \\ University of Kansas, Lawrence, Kansas \\ Corresponding author - H. W. Catts, University of Kansas, \\ Department of Speech-Language-Hearing, 1000 Sunnyside Ave., \\ Lawrence, KS 66045; email catts@ku.edu
}

\begin{abstract}
In this paper, we present a brief overview of the language basis of reading and reading disabilities. First, we describe the "Simple View of Reading," a model of reading that comprises two primary components, word recognition and language comprehension. We then review research showing that language problems underlie most difficulties children have learning to read. Lastly, we discuss implications of these findings for early identification and remediation of reading disabilities.
\end{abstract}

Each year thousands of young children begin to receive formal instruction in reading as they enter school. Although most of these children learn to read with relative ease, approximately $10 \%$ have significant difficulty acquiring proficient reading skills (Shaywitz \& Shaywitz, 1994). As a result of their reading problems, these children often go on to struggle in school and beyond (Lyon, 1998). Because of the potential impact of literacy problems, educators and researchers have actively pursued the development of effective programs for the early identification and treatment of reading disabilities (Snow, Burns, \& Griffin, 1998). Central to this work has been the search for the cause of reading disabilities. In this paper we report on some of the efforts to identify the cause(s) of reading disabilities. We argue that while attention has been given to visual perceptual problems, especially in the media, the best 
evidence for a causal basis of reading disabilities comes from studies of language difficulties in poor readers. This work also currently has the most direct implications for educational/clinical intervention. Therefore, in this paper, we review research concerning the language basis of reading disabilities and highlight the implications of this work for early identification and remediation. First, we briefly consider the status of research into the visual basis of reading disabilities.

\section{Visual Perceptual Deficits}

For many years, it was assumed that a deficit in visual perception was the major factor contributing to a child's difficulty in learning to read. Reading was seen as something done with one's eyes, and thus, problems in vision seemed to be a likely cause of reading difficulties. Beyond the "common sense" appeal of this view, the frequent reports of reversal errors in poor readers have reinforced a visual-based explanation of reading disabilities. Even today, most laypersons and many educators associate dyslexia with reading letters or words backwards. Despite this common view, there is surprisingly little empirical evidence to support the significance of reversal errors. The few studies that have examined these errors have shown that poor readers actually don't make that many reversal errors, and when they do, these errors don't seem to be the result of a visual perceptual problem (Fischer, Liberman, \& Shankweiler, 1978; Terepocki, Kruk, \& Willows, 2002; Vellutino, Pruzek, Steger, \& Meshoulam, 1973; Vellutino, Steger, DeSetto, \& Phillips, 1975). Other research has further found that individual differences in visual discrimination and visual memory during the preschool years are not particularly good predictors of reading achievement in the early school years (see Scarborough, 1998).

Most recently, there has been increased interest in the role of deficits in the transient visual system as a cause of reading disabilities (Cornelissen, Richardson, Mason, Fowler, \& Stein, 1995; Demb, Boynton, Best, \& Heeger, 1998; Lovegrove, 1992; Lovegrove, Martin, \& Slaghuis, 1986; Eden et al., 1996; Lehmkuhle, Garzia, Turner, Hash, \& Baro, 1993; Livingstone, Rosen, Drislane, \& Galaburda, 1991). The transient system (or what is also known as the magnocellular visual pathway) is one of two basic visual processing systems that are critical for many visual tasks including reading. Deficits in the transient 
system are argued to cause visual images to persist and to result in visual confusions while reading (Lovegrove et al., 1986). Transient system deficits have also begun to be linked with problems in other aspects of sensory processing and/or cerebellar functioning found in some poor readers (Stein, 2001).

Whereas research in the above area has drawn much attention, it is unclear at this point what role transient processing deficits might play in reading disabilities. Not all studies have found support for these deficits in poor readers (e.g., Hayduk, Bruck, \& Cavanagh, 1992; Olson \& Datta, 2002). Furthermore, in some studies that have supported transient deficits, these visual deficits have been found to overlap with language problems (Eden, Stein, Wood, \& Wood, 1995; Slaghuis, Twell, \& Kingston, 1996). More work will be needed to clarify the role of transient deficits in reading disabilities. For example, it would be important to find a group of poor readers with a history of these deficits, but without problems in language (Share \& Stanovich, 1995). If such children did exist, they could represent an important subgroup of children with reading disabilities.

\section{Language Basis of Reading Disabilities}

While evidence for the visual basis of reading disabilities is not yet convincing, a large body of research supports language deficits as a proximal cause of reading disabilities. ${ }^{*}$ Underlying this work is a strong theoretical foundation. At the heart of this foundation is the fact that writing systems are based on language (DeFrances, 1989). With few exceptions, the symbols used in the writing systems of the world represent language units. Whereas initially some symbol systems relied on pictograms or logograms to represent whole words or morphemes, written languages soon moved to systems that repre-

* The term "proximal cause" is used here to indicate that language problems are the most direct antecedent causal factor in many reading disabilities. We acknowledge that language problems themselves can be related to factors further down the causal chain, such as genetic or neurological abnormalities, which may have effects that go beyond language difficulties. However, current research suggests that in most cases it is the language deficits, and not these other effects, that have the most direct impact on learning to read. 
sented the sounds in words. In doing so, writing systems became transcriptions of what might be said orally. Today, the written languages of the world make use of various phonetic transcription systems to communicate through print. In all cases, what is written is language. As a result, the words, sentences, and discourse units of written language overlap heavily with those found in spoken language (Kamhi \& Catts, 1999). Clearly, there are functional as well as linguistic differences between spoken and written language, but for the most part, readers and listeners use similar linguistic knowledge and processes.

Given the nature of written language, it follows that to learn to read, the beginning reader needs to decode the written words into speech units and then comprehend the words (and sentences/ discourse) to derive meaning. This view of reading is described by Gough and colleagues in what they call the Simple View of Reading (Gough \& Tunmer, 1986; Hoover \& Gough, 1990). According to this view, reading is composed of word recognition and language comprehension. Word recognition is the translation of print into language (i.e., sounds and words) and comprehension is the making sense of language. While this is an oversimplified view of reading, it has been useful in directing researchers and educators to the locus of reading problems (see below).

\section{Phonological Processing}

Phonological Awareness

Most poor readers have significant problems learning to decode words (i.e., word recognition in the above model). In the search for the cause of these problems, one particularly fruitful area of research has been phonological processing, especially phonological awareness (Brady \& Shankweiler, 1991; Catts \& Kamhi, 1999; Goswami, 2002; Stanovich, 1988; Wagner \& Torgesen, 1987). Phonological awareness is the explicit awareness of the sounds of speech independent of meaning (Stanovich, 1988; Torgesen, 1996, 1999). Phonological awareness allows children to match sounds with letters and use this knowledge to phonetically decode words.

Initially, it was assumed that if children could talk and understand spoken language when they entered school, they should have no problems in phonological awareness. However, research has shown that 
there is considerable variability in phonological awareness even among children with apparently normal language development, and that this variability is closely related to reading achievement (Stanovich, 1988). Numerous studies have demonstrated that children with reading disabilities (RD) have deficits in phonological awareness (Bradley \& Bryant, 1983; Fletcher et al., 1994; Fox \& Routh, 1980; Olson, Wise, Conners, Rack, \& Fulker, 1989). In fact, Torgesen (1996) argued that “dyslexic children are consistently more impaired in phonological awareness than any other single ability" (p. 6). In an early investigation, Bradley and Bryant (1983) documented just how impaired phonological awareness abilities can be in some poor readers. In this study, they compared ten-year-old children with RD to six-and-one half-year-old, typically developing children matched on their reading ability. The children completed a phonological awareness oddity task in which they had to choose the odd item from a list of spoken words, such as hat, pat, dig, and sat. Despite the fact that the children with RD were three and onehalf years older than the typically developing readers, they performed significantly less well on this task.

Of course, it is possible that some of the deficits in phonological awareness observed in poor readers could be due to their reading problems. Because of the abstract nature of phonology, instruction and practice in an alphabetic orthography leads to a more explicit awareness of phonemes (Morais, Bertelson, Cary, \& Alegria, 1986, Morais, Cary, Alegria, \& Bertelson, 1979; Read \& Ruyter, 1985). Thus, children with RD might also be expected to have some deficits in phonological awareness as a result of their poor reading abilities. Because poor readers have less experience and skill in using the alphabet, they may not acquire the same level of speech sound awareness as their normal reading peers.

Whereas some problems in phonological awareness may be the result of reading disabilities, this is clearly not always the case. Research demonstrates that difficulties in phonological awareness are apparent in at-risk children even prior to beginning reading instruction, and that these deficits lead to subsequent problems in learning to read. For example, Catts, Fey, Zhang, and Tomblin (1999) showed that children in the 2nd grade with RD often had had deficits in phonological awareness in kindergarten. In addition, multiple regression analyses demonstrated that kindergarten performance in phonologi- 
cal awareness was a strong predictor of word recognition abilities in 2nd grade. Results also showed that phonological awareness continued to be a good predictor of reading even after kindergarten letter naming ability (a measure, in part, of alphabetic experience) was taken into consideration. Thus, differences in exposure to the alphabet during the preschool years alone cannot explain the variability in phonological awareness and associated differences in reading achievement (also see Badian, 1994; Felton, 1992; Mann, 1993; Torgesen, Wagner, \& Rashotte, 1994).

Training studies offer the best evidence of the impact of phonological awareness on reading (Alexander, Anderson, Heilman, Voeller, \& Torgesen, 1991; Hatcher, Hulme, \& Ellis, 1994; Torgesen et al., 2001; Wise, Ring, \& Olson, 1999). In these studies, children were provided with phonological awareness training and were subsequently evaluated for phonological awareness ability and reading achievement. In general, this work has shown that training in phonological awareness increases speech sound awareness, and in turn, improves reading achievement (Foorman \& Torgesen, 2001; Foorman, Francis, Fletcher, Mehta, \& Schatschneider, 1998). The results of this research, however, are not completely straightforward. For example, phonological awareness training needs to be combined with other instruction (sound-letter correspondence) to be most effective. This has led Share and Stanovich (1995) to argue that phonological awareness may be better described as a co-requisite to learning to read. Also, not all at-risk children seem to profit from phonological awareness training. Despite these and other limitations, training studies indicate that phonological awareness does play a causal role in reading disabilities.

\section{Phonological Memory}

Phonological memory deficits have also been reported in children with RD (Hulme, 1988; Jorm \& Share, 1983; Torgesen, 1985). Phonological memory, or phonological coding, refers to the encoding and storing of phonological information in memory. Phonological memory has been assessed through memory span tasks involving strings of verbal items, such as digits, letters, and words. Children with RD perform poorly on these tasks when compared to good readers (Cohen \& Netley, 1981; Mann, Liberman, \& Shankweiler, 1980; Rapala \& 
Brady, 1990; Shankweiler, Liberman, Mark, Fowler, \& Fischer, 1979; Stone \& Brady, 1995).

Studies have also compared good and poor readers' ability to repeat multisyllabic nonwords spoken by an examiner. These studies examine phonological memory by using nonwords that factor out semantic knowledge. For example, in an early investigation, Snowling (1981) reported that dyslexic children made more errors than readingage matched peers in the repetition of nonwords such as bagmivishent. In a follow-up study, Snowling and colleagues (Snowling, Goulandris, Bowlby, \& Howell, 1986) found that dyslexic children performed worse in repetition of low-frequency real words and nonwords when compared to age-matched and reading-matched children. Subsequent studies have further confirmed these findings (Catts, 1986; Kamhi, Catts, Mauer, Apel, \& Gentry, 1988; Stone \& Brady, 1995).

Similar to phonological awareness, deficits in phonological memory identified in kindergarten are predictive of reading achievement in the primary grades (Ellis \& Large, 1987; Mann \& Liberman, 1984; Torgesen et al., 1994). Measures of phonological memory, however, do not always account for variability in reading achievement independent of measures of phonological awareness (Torgesen et al., 1994; Wagner et al., 1987; Wagner, Torgesen, \& Rashotte, 1994). These findings have led researchers to speculate that deficits in phonological memory and phonological awareness stem from a common source, namely, deficiencies in the quality of phonological representations. Such deficiencies again could make it difficult for poor readers to learn how the alphabet is related to spoken words.

\section{Phonological Retrieval}

Children with RD also frequently have problems in phonological retrieval. Clinical observations have shown that poor readers often have word-finding difficulties and are sometimes described as dysnomic (Rudel, 1985). Word-finding problems include substitutions (e.g., "knife" for "fork"), circumlocutions (e.g., "you know, what you eat with"), and overuse of words lacking specificity (e.g., stuff, thing). It is often assumed that because individuals with RD seem to know the words they are looking for, that these naming problems are due to difficulties in recalling phonological information. Problems re- 
trieving phonological information, in turn, could explain why many poor readers fail to develop fluent word recognition, especially in oral reading.

The word-finding difficulties observed clinically in individuals with RD have also been borne out in research. Studies have consistently shown that poor readers perform less well than good readers on confrontation picture naming tasks (Catts, 1986; Denckla \& Rudel, 1976a; German, 1979; Wolf, 1984). For example, Denckla and Rudel (1976a) administered the Oldfield-Wingfield Picture-Naming Test to dyslexic, nondyslexic learning disabled (LD), and normal achieving children. Dyslexic children were slower and made more errors on this naming task than did nondyslexic LD and normal children. Because the performances of the dyslexic and normal children were similar on a test of receptive vocabulary, the researchers concluded that the naming deficits observed in dyslexic children were most likely due to retrieval problems.

Studies using serial naming tasks have provided the best evidence of phonological retrieval deficits in children with RD. These tasks, often referred to as rapid naming or rapid automatized naming tasks, require the individual to quickly and automatically say the name of a series of letters, numbers, familiar objects, or colors. Because the names of the items are quite common, storage factors are likely to play little role in these tasks. Consequently, rapid naming tasks may be thought of as a more "pure" measure of naming retrieval than other confrontation naming tasks.

Children with RD have been found to be slower on rapid naming tasks than are normal children (Denckla \& Rudel, 1976b; Vellutino, Scanlon, \& Spearing, 1995; Wolf, 1984). Studies also indicate that variability in rapid naming during the preschool years is predictive of reading achievement during the school years (Badian, 1994; Catts, 1993; Catts et al., 1999; Felton, 1992; Wolf Bally, \& Morris, 1986). Research further indicates that rapid naming explains unique variance in reading achievement beyond phonological awareness (Badian, 1994; Bowers \& Swanson, 1991; Catts, 1993). The latter evidence has led to the proposal of a double deficit in some poor readers (Wolf, Bowers, \& Biddle, 2000). Wolf and her colleagues argue that children at-risk for RD may have deficits in either or both phonological awareness and rapid naming. They further propose that if a child has problems in 
both areas, what they call a double deficit, he or she will have more pronounced difficulty learning to read than if problems are limited to one area (but see Schatschneider, Carlson, Francis, Foorman, \& Fletcher, 2002). Finally, Wolf et al. (2000) also raise the possibility that the problems poor readers have in rapid naming may go beyond deficits in phonological retrieval (also see Catts, Gillispie, Leonard, Kail, \& Miller, 2002). They argue that rapid naming not only involves accessing a phonological code, but it also includes a demanding array of attentional, perceptual, memory, lexical, and articulatory processes. Regardless, with its combination of rapid, serial processing and integration of cognitive, linguistic, and motoric processes, rapid naming speed seems to provide a simpler approximation of the reading process.

\section{Language Comprehension}

Beyond problems in phonological processing, poor readers often have difficulties in other aspects of language. Research has shown that these children have deficits in vocabulary (Fry, Johnson, \& Muehl, 1970; Wiig \& Semel, 1975), morphology and syntax (Doehring, Trites, Patel, \& Fiedorowitcz, 1981; Fletcher, 1981; Stanovich \& Siegel, 1994; Vogel, 1974), and text-level processing (Feagans \& Short, 1984; Roth \& Spekman, 1986; Smiley, Oakley, Worthen, Campione, \& Brown, 1977; Stothard \& Hulme, 1992; Yuill \& Oakhill, 1991). Similar to deficits in phonological processing, these language problems can impact word decoding. For example, a small vocabulary can limit the number of words available for recognition, while other language deficits can reduce the contextual knowledge a reader may use to identify a low frequency word (Nation \& Snowling, 1998). However, nonphonological language problems are likely to have their greatest influence on comprehension. Children with deficits in vocabulary, grammar, and text processing will most certainly have difficulties extracting meaning from printed text. Although the research cited above suggests a causal relationship between nonphonological language problems and reading disabilities, it is far from conclusive. A major problem in the interpretation of this work is that in most cases language abilities were examined in children who had had reading problems for several years. 
This makes it difficult to determine if the observed language deficits are the cause or the consequence of reading problems. Because poor readers generally do not read as much as good readers, and as a result, have less exposure to the language in printed text, they may develop some aspects of language more slowly than good readers (Stanovich, 1986).

Not all studies of language problems in children with RD have examined reading and language abilities concurrently. Some studies have investigated language deficits in poor readers prior to their learning to read.

For example, in a recent longitudinal study, Catts et al. (1999) followed a group of 604 children from kindergarten into 2nd grade. Language abilities and reading achievement were assessed. This testing identified 183 children who were reading at least $1 S D$ below the mean. The performance of these poor readers on kindergarten language tests was compared to that of a normal control group. Weighted scores based on epidemiologic data from the same sample (Tomblin et al., 1997) were used to ensure that the results were representative of poor readers from the general population. Findings indicated that poor readers performed significantly less well than good readers on kindergarten tests of vocabulary, grammar, and/or narration. In addition, approximately $60 \%$ of the poor readers had a language composite score in kindergarten that was at least $1 S D$ below normal. This compared to a rate of only approximately $10 \%$ in good readers. These results thus indicate that problems in vocabulary, grammar, and/or narration may often precede and influence reading achievement.

\section{Follow-Up Studies Of Children With Language Impairments}

Evidence of a link between early language problems and subsequent reading disabilities also comes from follow-up studies of children diagnosed with developmental language impairments. In these studies, children who experienced difficulties in the development of spoken language (generally delays in vocabulary or grammar or both) were identified in preschool or kindergarten and followed into the school years (Bishop \& Adams, 1990; Catts, 1993; Silva, McGree, \& Williams, 1987; Stark et al., 1984; Stothard, Snowling, Bishop, Chipchase \& Kaplan (1998). If language problems play a causal role 
in reading disabilities, such children should have a high incidence of reading disabilities. This has generally proven to be the case. Research has shown that $50 \%$ or more of children with language impairments go on to have reading disabilities in the primary or secondary grades.

In the most comprehensive follow-up study to date, the first author and colleagues (Catts, Fey, Tomblin, \& Zhang, 2002) investigated the reading outcomes of approximately 200 kindergarten children with language impairments. These children were a subsample of those who participated in the study by Catts et al. (1999) that was described above. In kindergarten, the participants were administered tests of language and nonverbal abilities. In 4th grade, reading was assessed by measures of reading comprehension (and word recognition). The results indicated that $52.9 \%$ of the children with language impairments performed one or more standard deviations below the mean on a composite measure of reading comprehension. This rate of reading problems is approximately 5 times that found in the normal language control group (8.6\%). Further analyses indicated that children with lower nonverbal abilities in addition to a language impairment performed significantly less well in reading achievement than did those with higher nonverbal IQs. Severity of the language impairment in kindergarten was also found to be related to reading outcome. However, the factor most closely associated with reading achievement in children with language impairments was improvements in language abilities. Children who reached the highest levels of language in 4th grade had the best outcomes in reading achievement. Such a finding clearly illustrates the close tie between developing language skills and reading achievement.

\section{Educational/Clinical Implications}

\section{Early Identification}

Research on the language basis of reading disabilities has led to significant advancements in the early identification and remediation of reading disabilities (Catts \& Kamhi, 1999; Simmons \& Kameenui, 1998; Snow et al., 1998). Because research indicates that reading disabilities 
often manifest themselves as language difficulties during the preschool years, the latter problems can be used to identify children who are at risk and provide them with the early intervention that is necessary to prevent or limit reading disabilities.

Research reviewed above indicates that during the preschool years, the most prominent sign of potential for reading disabilities is the presence of a developmental language impairment. As reported above, children with language impairments have a very high incidence of subsequent reading disabilities. These children are often identified by speech-language pathologists prior to school entry, and many are provided with language intervention. While these efforts have sometimes been carried out with future literacy needs in mind (Dale, Notari, Crain-Thoreson, \& Cole, 1993; Whitehurst, Fischel, Caufield, DeBaryshe, \& Valdez-Menchaca, 1989), much more attention needs to be given to the link between early language impairments and reading disabilities, as well as the type and intensity of intervention that is necessary to reduce language-impaired children's risk for reading disabilities.

Children with milder language impairments and/or problems in phonological processing should also be considered at risk for reading disabilities. Screening instruments used to evaluate preschool and kindergarten children have typically not been sensitive to the identification of these children. However, there are a variety of measurement instruments and protocols that are now available to identify children who are at risk for reading problems (Catts \& Kamhi, 1999; Scarborough, 1998; Torgesen \& Mathis, 2000). Research has shown that single tests of language abilities are predictive of subsequent reading achievement, but a combination of tests tapping several domains is the most reliable form of assessment (Scarborough, 1998). Studies using multiple measures of language ability (in combination with other indices) have been quite successful in predicting reading outcomes in young children (Badian, 1994; Butler, Marsh, Sheppard, \& Sheppard, 1985; Catts, Fey, Tomblin, \& Zhang, 2001; Hurford et al., 1994). For example, in a recent study (Catts et al., 2001), we found that a battery of tests in kindergarten could predict reading status in 2nd grade with approximately $90 \%$ accuracy. This battery included measures of phonological awareness, rapid naming, sentence imitation, letter identification, and mother's 
level of education. These measures are described in detail and the procedures for using them for early identification purposes is highlighted in the Catts et al. (2001) paper.

\section{Remediation}

Research on the language basis of reading disabilities also has implications for remediation. This work suggests that children with reading problems can benefit from remediation directed toward the language problems that underlie reading disabilities. Catts and Kamhi (1999) suggest that a classification system based on the Simple View of Reading may be useful in directing initial intervention efforts. This model proposes that poor readers (those with problems in reading comprehension) can be divided into individuals with difficulties in word recognition and/or language comprehension. (A similar division can be made in preschool children on the basis of children's risk for problems in these areas.) According to this scheme, one subgroup of poor readers, typically referred to as dyslexic, has poor word recognition abilities (also often have problems in phonological processing), but at least adequate language comprehension. Another subgroup has poor word recognition abilities and poor language comprehension. We call these children language-learning disabled. The Simple View also suggests the possibility of a third subgroup. This subgroup, referred to as hyperlexic, has adequate word recognition, but poor language comprehension. Thus, all three subgroups have reading comprehension problems but for different reasons.

Several recent studies have used this classification system to identify subgroups of poor readers (Aaron, Joshi, \& Williams, 1999; Catts, Hogan, \& Fey, 2003). This work has shown that poor readers can be divided on the basis of the model. This division does not, however, lead to homogeneous subgroups with clear demarcations between them. Rather poor readers are spread throughout the two dimensional space involving word recognition and language comprehension abilities. Even though this is the case, the model does highlight the strengths and weaknesses of many poor readers across these dimensions. By considering children's strengths and weaknesses in word recognition and 
language comprehension, practitioners may be better able to describe reading problems, plan intervention, monitor progress, and determine prognosis (Aaron, 1991).

To implement this model, one would need to evaluate word recognition and language comprehension abilities. Numerous measures are available to assess word decoding abilities. Some measure accuracy of sight word reading or phonetic decoding (e.g., Woodcock Reading Mastery Tests-Revised; Woodcock, 1998), while others measure the rate or fluency of word reading (e.g., Test of Word Reading Efficiency; Torgensen et al., 1998). It might also be helpful to assess phonological processing (see Torgesen \& Mathis, 2000). The classification system also requires an assessment of spoken language comprehension (e.g., listening abilities). This assessment might include traditional measures of receptive vocabulary and grammatical knowledge (Carrow-Woolfolk, 1999; DiSimoni, 1978; Dunn \& Dunn, 1997), as well as measures of the comprehension of extended spoken text. Although standardized measures involving spoken texts are currently available (Newcomer, 2001; Semel, Wiig, \& Secord, 1998), it may be useful to use an alternative form of a reading comprehension test which can be read aloud to evaluate listening comprehension (Aaron, 1991).

Based on children's strengths and weaknesses, an intervention plan can be devised. Children with dyslexia or language-learning disabilities (or those at risk for these deficits) will require efforts directed at word recognition. Most of these children can benefit from training in phonological awareness. As reported above, numerous studies have shown that phonological awareness can be improved in most poor readers, or children at risk, and that this intervention can prevent or reduce reading difficulties (Alexander et al., 1991; Hatcher, et al., 1994; Torgesen et al., 2001; Wise et al., 1999). There are now numerous programs or materials commercially available to train phonological awareness (see Torgesen \& Mathis, 2000). These and other materials may be used in a variety of ways to set up an intervention program for children who have, or are at risk for, word recognition deficits. It is generally agreed, however, that for phonological awareness training to be effective, it needs to be combined with instruction in phonetic decoding (Torgesen, 1999). Again, a variety of programs can be used for this purpose (see Clark \& Uhry, 1995; Moats \& Foorman, 1997). The programs that provide explicit, systematic, sup- 
portive, and intensive training in how to phonetically decode printed words will be the most effective (Torgesen, 1999). More recent programs have also become concerned with the issue of fluency of word decoding (Lovett, Lacerenza, \& Borden, 2000; Wolf, Miller, \& Donnelly, 2000).

Remediation for children with language-learning disabilities (or those at risk for these difficulties) will need to focus on language comprehension as well as word recognition. Also, comprehension will be the primary focus of intervention for children with hyperlexia. The aspect of comprehension that has had the greatest attention over the years has been vocabulary. Research has shown that vocabulary instruction can be effective, especially if strategies are taught that allow children to become independent word learners (Baker, Simmons, \& Kameenui, 1998a, 1998b). Language intervention for poor readers has also focused on grammatical understanding and text-level processing (Dickson, Simmons, \& Kameenui, 1998a, 1998b; Norris \& Hoffman, 1993; Westby, 1999). For example, poor readers have been taught how particular grammatical structures operate in printed text. Poor readers have also been instructed in how to use story grammar or expository text structure for comprehension purposes (e.g., Williams, Brown, Silverstein, \& deCani, 1994). Finally, considerable efforts have focused on teaching poor readers comprehension strategies (Dickson, Collins, Simmons, \& Kameenui, 1998). These have included strategies for comprehension monitoring, mental imagery, question generation, and summarization. These strategies and other approaches should be effective in reducing the language comprehension problems experienced by children with language-learning disabilities or hyperlexia (see Gersten, Fuchs, Williams, \& Baker, 2001). A strategic approach could also benefit children with dyslexia by providing them support while they learn to improve their decoding skills.

\section{Summary}

In this paper, we have provided a relatively brief discussion of the language basis of reading and reading disabilities. We introduced a model of reading that involved two primary components, word recognition and language comprehension. We then reviewed research that 
indicates that language problems underlie many difficulties children have in learning these components of reading. Finally, we discussed the implications of this work for the early identification and remediation of reading disabilities.

Our treatment of these topics has been rather straightforward and simple. Perhaps it has been too simple. Indeed, if we have learned anything about reading in recent years, it is that it is far more complex than anyone thought. In fact, reading may be the most complex cognitive activity that we humans learn. Therefore, to understand reading and to effectively deal with reading disabilities, we will likely need complex models and intervention programs. However, models and programs need to rest on a solid foundation. We feel that the Simple View of Reading and its linguistic underpinnings provide a start to such a foundation, and it is in this regard that we offer the above suggestions.

\section{References}

Aaron, P. G. (1991). Can reading disabilities be diagnosed without using intelligence tests? Journal of Learning Disabilities, 24, 178-186.

Aaron, P. G., Joshi, M., \& Williams, K. A. (1999). Not all reading disabilities are alike. Journal of Learning Disabilities, 32, 120-137.

Alexander, A., Andersen, H. G., Heilman, P. C., Voeller, K. K. S., \& Torgesen, J. K. (1991). Phonological awareness training and remediation of analytic decoding deficits in a group of severe dyslexics. Annals of Dyslexia, 41, 193-207.

Badian, N. A. (1994). Preschool prediction: Orthographic and phonological skills, and reading. Annals of Dyslexia, 44, 3-25.

Baker, S. K., Simmons, D. C., \& Kameenui, E. J. (1998a). Vocabulary acquisition: Research bases. In D.C. Simmons \& E. J. Kameenui (Eds.), What reading research tells us about children with diverse learning needs: Bases and basics (pp. 183218). Mahwah, NJ: Erlbaum.

Baker, S. K., Simmons, D. C., \& Kameenui, E. J. (1998b). Vocabulary acquisition: Instructional and curricular bases and implications. In D. C. Simmons \& E. J. Kameenui (Eds.), What reading research tells us about children with diverse learning needs: Bases and basics (pp. 219-238). Mahwah, NJ: Erlbaum.

Bishop, D. V. M., \& Adams, C. (1990). A prospective study of the relationship between specific language impairment, phonological disorders, and reading retardation. Journal of Child Psychology and Psychiatry, 31, 1027-1050.

Bowers, P. G., \& Swanson, L. B. (1991). Naming speed deficits in reading disability: Multiple measures of a singular process. Journal of Experimental Child Psychology, 51, 219. 
Bradley, L., \& Bryant, P. (1983). Categorizing sounds and learning to read: A causal connection. Nature, $31,419-421$.

Brady, S. A., \& Shankweiler, D. P. (Eds.). (1991). Phonological processes in literacy: A tribute to Isabelle Y. Liberman. Hillsdale, NJ: Erlbaum.

Butler, S. A., Marsh, H. W., Sheppard, M. J., \& Sheppard, J. L. (1985). Seven-year longitudinal study of the early prediction of reading achievement. Journal of Educational Psychology, 77, 349-361.

Carrow-Woolfolk, E. (1999). Test for Auditory Comprehension of Language (3rd ed.). Chicago: Riverside Publishing.

Catts, H. W. (1986). Speech production/phonological deficits in reading-disordered children. Journal of Learning Disabilities, 19, 504-508.

Catts, H. W. (1993). The relationship between speech-language impairments and reading disabilities. Journal of Speech and Hearing Research, 36, 948- 958.

Catts, H. W., Fey, M. E., Tomblin, J. B., \& Zhang, X. (2001). Estimating the risk of future reading difficulties in kindergarten children: A research-based model and its clinical implications. Language, Speech, and Hearing Services in Schools, $32,38-50$.

Catts, H. W., Fey, M. E., Tomblin, J. B., \& Zhang, X. (in press). A longitudinal investigation of reading outcomes in children with language impairments. Journal of Speech, Language, and Hearing Research.

Catts, H. W., Fey, M. E., Zhang, X., \& Tomblin, J. B. (1999). Language basis of reading and reading disabilities: Evidence from a longitudinal investigation. Scientific Studies of Reading, 3, 331-361.

Catts, H. W., Gillispie, M., Leonard, L. B., Kail, R. V., \& Miller, C. A. (2002). The role of speed of processing, rapid naming, and phonological awareness in reading achievement. Journal of Learning Disabilities, 35, 509-524.

Catts, H. W., Hogan, T. P. E., \& Fey, M. (2003). Subgrouping poor readers on the basis of individual differences in reading-related abilities. Journal of Learning Disabilities, 36, 151-164.

Catts, H. W., \& Kamhi, A. G. (Eds.). (1999). Language and reading disabilities. Needham Heights, MA: Allyn \& Bacon.

Clark, D. B., \& Uhry, J. K. (1995). Dyslexia: Theory and practice of remedial instruction. Baltimore: York Press.

Cohen, R. L., \& Netley, C. (1981). Short-term memory deficits in reading disabled children in the absence of opportunity for rehearsal strategies. Intelligence, 5, 69-76.

Cornelissen, P., Richardson, A., Mason, A., Fowler, S., \& Stein, J. (1995). Contrast sensitivity and coherent motion detection measured at photopic luminance levels in dyslexics and controls. Vision Research, 35, 1483-1494.

Dale, P., Notari, A., Crain-Thoreson, C., \& Cole, K. (1993). Parent-child storybook reading as an intervention technique for young children with language delays. Paper 
presented at the Society for Research in Child Development annual meeting, New Orleans, LA, March 1993.

DeFrancis, J. (1989). Visible speech: The diverse oneness of writing systems. Honolulu, HI: University of Hawaii Press.

Demb, J. B., Boynton, G. M., Best, M., \& Heeger, D. J. (1998). Psychophysical evidence for a magnocellular deficit in dyslexics. Vision Research, 38, 1555- 1559 .

Denckla, M. B., \& Rudel, R. G. (1976a). Naming of object-drawings by dyslexic and other leaning disabled children. Brain and Language, 3, 1-15.

Denckla, M. B., \& Rudel, R. G. (1976b). Rapid automatized naming (RAN): Dyslexia differentiated from other learning disabilities. Neuropsychologia, 14, 471-479.

Dickson, S. V., Collins, V. L., Simmons, D. C., \& Kameenui, E. J. (1998). Metacognitive strategies: Research bases. In D. C. Simmons \& E. J. Kameenui (Eds.), What reading research tells us about children with diverse learning needs: Bases and basics (pp. 295-360). Mahwah, NJ: Erlbaum.

Dickson, S. V., Simmons, D. C., \& Kameenui, E. J. (1998a). Text organization: Research bases. In D. C. Simmons \& E. J. Kameenui (Eds.), What reading research tells us about children with diverse learning needs: Bases and basics (pp. 239-278). Mahwah, NJ: Erlbaum.

Dickson, S. V., Simmons, D. C., \& Kameenui, E. J. (1998b). Text organization: Instructional and curricular basics and implications. In D. C. Simmons \& E. J. Kameenui (Eds.), What reading research tells us about children with diverse learning needs: Bases and basics (pp. 279-294). Erlbaum.

DiSimoni, F. (1978). Token Test for Children. Chicago: Riverside Publishing.

Doehring, D., Trites, R., Patel, P., \& Fiedorowitcz, C. (1981). Reading difficulties: The interaction of reading, language, and neuropsychological deficits. New York: Academic Press.

Dunn, L., \& Dunn, L. (1997). Peabody Picture Vocabulary Test (3rd ed.). Circle Pines, MN: American Guidance Service.

Eden, G. F., Stein, J. F., Wood, M. H., \& Wood, F. B. (1995). Verbal and visual problems in reading disability. Journal of Learning Disabilities, 28, 272-290.

Eden, G. F., VanMeter, J., Rumsey, J., Maisog, J., Woods, R., \& Zeffiro, T. (1996). Abnormal processing of visual motion in dyslexia revealed by functional brain imaging. Nature, 382, 66-69.

Ellis, N., \& Large, B. (1987). The development of reading: As you seek so shall you find. British Journal of Psychology, 78, 1-28.

Feagans, L., \& Short, E. (1984). Developmental differences in the comprehension and production of narratives by reading disabled and normally achieving children. Child Development, 55, 1727-1736.

Felton, R. H. (1992). Early identification of children at risk for reading disabilities. Topics in Early Childhood and Special Education, 12, 212-229. 
Fischer, F. W., Liberman, I. Y., \& Shankweiler, D. (1978). Reading reversals and developmental dyslexia: A further study. Cortex, 14, 496-510.

Fletcher, J. M. (1981). Linguistic factors in reading acquisition: Evidence for developmental changes. In F. J. Pirozzolo \& M. D. Wittrock (Eds.), Neuropsychological and cognitive processes in reading (pp. 274-294). New York: Academic Press.

Fletcher, J. M., Shaywitz, S. E., Shankweiler, D. P., Katz, L., Liberman, I. Y., Stuebing, K. K., Francis, D. J., et al. (1994). Cognitive profiles of reading disability: Comparisons of discrepancy and low achievement definitions. Journal of Educational Psychology, 86, 6-23.

Foorman, B. R., \& Torgesen, J. (2001). Critical elements of classroom and smallgroup instruction promote reading success in all children. Learning Disabilities: Research and Practice, 16, 203-212.

Foorman, B. R., Francis, D. J., Fletcher, J. M., Mehta, P., \& Schatschneider, C. (1998). The role of instruction in learning to read: Preventing reading failure in at-risk children. Journal of Educational Psychology, 90, 37-55

Fox, B., \& Routh, D. K. (1980). Phonemic analysis and severe reading disability in children. Journal of Psycholinguistic Research, 9, 115-119.

Fry, M. A., Johnson, C. S., \& Muehl, S. (1970). Oral language production in relation to reading achievement among select second graders. In D. Baker \& P. Satz (Eds.), Specific reading disability: Advances in theory and method (pp. 123159). Rotterdam: Rotterdam University Press.

German, D. J. (1979). Word-finding skills in children with learning disabilities. Journal of Learning Disabilities, 12, 43-48.

Gersten, R. M., Fuchs, L. S., Williams, J. P., \& Baker, S. (2001). Teaching reading comprehension strategies to students with learning disabilities: A review of research. Review of Educational Research, 71, 279-320.

Goswami, U. (2002). Phonology, reading development, and dyslexia: A cross-linguistic perspective. Annals of Dyslexia, 52, 141-163.

Gough, P. B., \& Tunmer, W. E. (1986). Decoding, reading, and reading disability. Remedial and Special Education, 7, 6-10.

Hatcher, P., Hulme, C., \& Ellis, A. W. (1994). Ameliorating early reading failure by integrating the teaching of reading and phonological skills: The phonological linkage hypothesis. Child Development, 65, 41-57.

Hayduk, S., Bruck, M., \& Cavanagh, P. (1992). Do adult dyslexics show low-level visual processing deficits? Paper presented at the Rodin Remediation Society, New York Academy of Sciences, New York.

Hoover, W. A., \& Gough, P. B. (1990). The simple view of reading. Reading and Writing: An Interdisciplinary Journal, 2, 127-160.

Hulme, C. (1988). Short-term memory development and learning to read. In M. Gruneberg, P. Morris, \& R. Sykes (Eds.), Practical aspects of memory: Current 
research and issues; Vol. 2, Clinical and educational implications (pp. 234-271). Chichester, England: Wiley.

Hurford, D. P., Johnston, M., Nepote, P., Hampton, S., Moore, S., Neal, J., Mueller, A., et al. (1994). Early identification and remediation of phonological-processing deficits in first-grade children at risk for reading disabilities. Journal of Learning Disabilities, 22, 647-659.

Jorm, A. F., \& Share, D. (1983). Phonological recoding and reading acquisition. Applied Psycholinguistics, 4, 103-147.

Kamhi, A. G., \& Catts, H. W. (1999). Language and reading: Convergences and divergences. In H. W. Catts \& A. G. Kamhi (Eds.), Language and reading disabilities (pp. 1-24). Needham Heights, MA: Allyn \& Bacon.

Kamhi, A. G., Catts, H. W, Mauer, D., Apel, K., \& Gentry, B. (1988). Phonological and spatial processing abilities in language and reading impaired children. Journal of Speech and Hearing Disorders, 53, 316-327.

Lehmkuhle, S., Garzia, R. P., Turner, L., Hash, T., \& Baro, J. A. (1993). A defective visual pathway in children with reading disability. New England Journal of Medicine, 328, 989-996.

Livingstone, M., Rosen, G., Drislane, F., \& Galaburda, A. (1991). Physiological and anatomical evidence for a magnocellular defect in developmental dyslexia. Proceedings of the National Academy of Science, 88, 7943-7947.

Lovegrove, W. (1992). The visual deficit hypothesis. In N. Singh \& I. Beale (Eds.), Learning disabilities: Nature, theory, and treatment. New York: Springer-Verlag.

Lovegrove, W., Martin, F., \& Slaghuis, W. (1986). The theoretical and experimental case for a visual deficit in specific reading disability. Cognitive Neuropsychology, 3, 225-267.

Lovett, M. W., Lacerenza, L., \& Borden, S. L. (2000). Putting struggling readers on the PHAST track: A program to integrate phonological and strategy-based remedial reading instruction and maximize outcomes. Journal of Reading Disabilities, 33, 458-476.

Lyon, G. R. (1998). Why learning to read is not a natural process. Educational Leadership, 55, 14-19.

Mann, V. A. (1993). Phoneme awareness and future reading ability. Journal of Learning Disabilities, 26, 259-269.

Mann, V. A., \& Liberman, I. Y. (1984). Phonological awareness and verbal shortterm memory. Journal of Learning Disabilities, 17, 592-599.

Mann, V. A., Liberman, I. Y., \& Shankweiler, D. (1980). Children's memory for sentences and word strings in relation to reading ability. Memory $\mathcal{E}$ Cognition, 329-335.

Moats, L. C., \& Foorman, B. R. (1997). Introduction to special issue of SSR: Components of effective reading instruction. Scientific Studies of Reading, 1, 187-189.

Morais, J., Bertelson, P., Cary, L., \& Alegria, J. (1986). Literacy training and speech segmentation. Cognition, 24, 45-64. 
Morais, J., Cary, L., Alegria, J., \& Bertelson, P. (1979). Does awareness of speech as a sequence of phones arise spontaneously? Cognition, 7, 323-331.

Nation, K., \& Snowling, M. J. (1998). Individual differences in contextual facilitation: Evidence from dyslexia and poor reading comprehension. Child Development, 69, 996-1011.

Newcomer, P. (2001). Diagnostic Achievement Battery - 3. Austin, TX: Pro-Ed.

Norris, J., \& Hoffman, P. (1993). Whole language intervention for school-age children. San Diego, CA: Singular Publishing Group.

Olson, R., \& Datta, H. (2002). Visual-temporal processing in reading-disabled and normal twins. Reading and Writing: An Interdisciplinary Journal, 15, 127- 149.

Olson, R., Wise, B., Conners, F., Rack, J., \& Fulker, D. (1989). Specific deficits in component reading and language skills: Genetic and environmental influences, Journal of Learning Disabilities, 22, 339-348.

Rapala, M. M., \& Brady, S. (1990). Reading ability and short-term memory: The role of phonological processing. Reading and Writing: An Interdisciplinary Journal, 2, 1-25.

Read, C., \& Ruyter, L. (1985). Reading and spelling skills in adults of low literacy. Remedial and Special Education, 6, 43-52.

Roth P., \& Spekman, N. J. (1986). Narrative discourse: Spontaneously generated stories of learning-disabled and normally achieving students. Journal of Speech and Hearing Disorders, 51, 8-23.

Rudel, R. (1985). The definition of dyslexia: Language and motor deficits. In F. H. Duffy \& N. Geschwind (Eds.), Dyslexia: A neuroscientific approach to clinical evaluation (pp. 33-53). Boston: Little, Brown \& Company.

Scarborough, H. S. (1990). Very early language deficits in dyslexic children. Child Development, 61, 1728-1743.

Scarborough, H. S. (1991). Early syntactic development of dyslexic children. Annals of Dyslexia, 41, 207-220.

Scarborough, H. S. (1998). Early identification of children at risk for reading disabilities: Phonological awareness and some other promising predictors. In B. K. Shapiro, P. J. Accardo, \& A. J. Capute (Eds.), Specific reading disability: A view of the spectrum. Timonium, MD: York Press.

Schatschneider, C., Carlson, C. D., Francis, D. J., Foorman, B. R., \& Fletcher, J. M. (2002). Relationship of rapid automatized naming and phonological awareness in early reading development: Implications for the double-deficit hypothesis. Journal of Learning Disabilities, 35, 245-256.

Semel, E., Wiig, E. H., \& Secord, W. (1998). Clinical Evaluation of Language Fundamentals - 3. San Antonio, TX: The Psychological Corporation.

Shankweiler, D., Liberman, I. Y., Mark, L. S., Fowler, C. A., \& Fischer, F. W. (1979). The speech code and learning to read. Journal of Experimental Psychology: Human Learning and Memory, 5, 531-545. 
Share, D. L., \& Stanovich, K. E. (1995). Cognitive processes in early reading development: Accommodating individual differences into a model of acquisition. Issues in Education, 1, 1-57.

Shaywitz, B. A., \& Shaywitz, S. E. (1994). Learning disabilities and attention disorders. In K. Swaiman (Ed.), Principles of pediatric neurology (pp. 1119-1151). St. Louis, MO: Mosby.

Silva, P. A., McGree, R., \& Williams, S. M. (1987). Developmental language delay from three to seven and its significance for low intelligence and reading difficulties at age seven. Developmental Medicine and Clinical Neurology, 783-793.

Simmons, D. C., \& Kameenui, E. J. (Eds.). (1998). What reading research tells us about children with diverse learning needs: Bases and basics. Mahwah, NJ: Erlbaum. Slaghuis, W., Twell, A., \& Kingston, K. (1996). Visual and language processing deficits are concurrent in dyslexia and continue into adulthood. Cortex, 32, 413-438.

Smiley, S. S., Oakley, D. D., Worthen, D., Campione, J. C., \& Brown, A. L. (1977). Recall of thematically relevant material by adolescent good and poor readers as a function of written versus oral presentation. Journal of Educational Psychology, 69, 381-387.

Snow, C. E, Burns, M. S., \& Griffin, P. (Eds.). Preventing reading difficulties in young children. Washington, DC: National Academy Press.

Snowling, M. (1981). Phonemic deficits in developmental dyslexia. Psychological Research, 43, 219-234.

Snowling, M. J., Goulandris, N., Bowlby, M., \& Howell, P. (1986). Segmentation and speech perception in relation to reading skill: A developmental analysis. Journal of Experimental Child Psychology, 41, 489-507.

Stanovich, K. E. (1986). Matthew effects in reading: Some consequences of individual differences in the acquisition of literacy. Reading Research Quarterly, 86, 360-406.

Stanovich, K. E. (1988). Children's reading and the development of phonological awareness. Detroit, MI: Wayne State University Press.

Stanovich, K. E., \& Siegel, L. S. (1994). The phenotypic performance profile of reading-disabled children: A regression-based test of the phonological-core variables difference model. Journal of Educational Psychology, 86, 24-53.

Stark, R. E., Bernstein, L. E., Condino, R., Bender, M., Tallal, P., \& Catts, H. (1984). Four-year follow-up study of language impaired children. Annals of Dyslexia, $34,49-67$.

Stein, J. (2001). The magnocellular theory of developmental dyslexia. Dyslexia, 7 , 12-36.

Stone, B., \& Brady, S. (1995). Evidence for phonological processing deficits in lessskilled readers. Annals of Dyslexia, 4, 51-78.

Stothard, S., \& Hulme, C. (1992). Reading comprehension difficulties in children: The role of language comprehension and working memory skills. Reading and Writing: An Interdisciplinary Journal, 4, 245-256. 
Stothard, S., Snowling, M., Bishop, D. V. M., Chipchase, B. B., \& Kaplan, C. A. (1998). Language-impaired preschoolers: A follow-up into adolescence. Journal of Speech, Language, and Hearing Research, 41, 407-418.

Terepocki, M., Kruk, R. S., Willows, D. M. (2002). The incidence and nature of letter orientation errors in reading disability. Journal of Learning Disabilities, 35, 214-233.

Tomblin, J. B., Records, N. L., Buckwalter, P., Zhang, X., Smith, E., \& O’Brien, M. (1997). The prevalence of specific language impairment in kindergarten children. Journal of Speech, Language, and Hearing Research, 40, 1245-1260.

Torgesen, J. K. (1985). Memory processes in reading disabled children. Journal of Learning Disabilities, 18, 350-357.

Torgesen, J. K. (1996). Phonological awareness: A critical factor in dyslexia. Baltimore: Orton Dyslexia Society.

Torgesen, J. K. (1999). Assessment and instruction for phonemic awareness and word recognition skills. In H. W. Catts \& A. G. Kamhi (Eds.), Language and reading disabilities (pp. 428-153). Needham Heights, MA: Allyn \& Bacon.

Torgesen, J. K., Alexander, A. W., Wagner, R. K., Rashotte, C. A., Voeller, K. K. S., \& Conway, T. (2001). Intensive remedial instruction for children with severe reading disabilities: Immediate and long-term outcomes from two instructional approaches. Journal of Learning Disabilities, 1, 33-58.

Torgesen, J. K., \& Mathis, P. G. (2000). A basic guide to understanding, assessing, and teaching phonological awareness. Austin, TX: Pro-Ed.

Torgesen, J. K., Wagner, R. K., \& Rashotte, C. A. (1994). Longitudinal studies of phonological processing and reading. Journal of Learning Disabilities, 27, 276- 286.

Torgesen, J. K., Wagner, R., \& Rashotte, C. (1998). Test of Word Reading Efficiency. Austin, TX: Pro-Ed.

Vellutino, F. R., Pruzek, R., Steger, J. A.., \& Meshoulam, U. (1973). Immediate visual recall in poor and normal readers as a function of orthographic-linguistic familiarity. Cortex, 9, 368-384.

Vellutino, F. R., Scanlon, D. M., \& Spearing, D. (1995). Semantic and phonological coding in poor and normal readers. Journal of Experimental Child Psychology, 59, 76-123.

Vellutino, F. R., Steger, J. A., DeSetto, L., \& Phillips, F. (1975). Immediate and delayed recognition of visual stimuli in poor and normal readers. Journal of Experimental Child Psychology, 59, 223-232.

Vogel, S. A. (1974). Syntactic abilities in normal and dyslexic children. Journal of Learning Disabilities, 7(2), 47-53.

Wagner, R., Balthazor, M., Hurley, S., Morgan, S., Rashotte, C., Shaner, R., Simmons, K., \& Stage, S. (1987). The nature of prereaders' phonological processing abilities. Cognitive Development, 2, 355-373. 
Wagner, R. K., \& Torgesen, J. K. (1987). The nature of phonological processing and its causal role in the acquisition of reading skills. Psychological Bulletin, 101, 1-21.

Wagner, R. K., Torgesen, J. K., \& Rashotte, C. A. (1994). Development of readingrelated phonological processing abilities: New evidence of bidirectional causality from a latent variable longitudinal study. Developmental Psychology, 30, 73-87.

Westby, C. E. (1999). Assessing and facilitating text comprehension problems. In H. W. Catts \& A. G. Kamhi (Eds.), Language and reading disabilities (pp. 154223). Needham Heights, MA: Allyn \& Bacon.

Whitehurst, G. F., Fischel, J. E., Caulfield, M., DeBaryshe, B. D., \& ValdezMenchaca, M. C. (1989). Assessment and treatment of early expressive language delay. In P. Aelazo \& R. Barr (Eds.), Challenges to developmental paradigms: Implications for assessment and treatment (pp. 113-135). Hillsdale: Erlbaum.

Wiig, E. H., \& Semel, E. M. (1975). Productive language abilities in learning disabled adolescents. Journal of Learning Disabilities, 8, 578-586.

Wise, B. W., Ring, J., \& Olson, R. K. (1999). Training phonological awareness with and without explicit attention to articulation. Journal of Exceptional Child Psychology, 72, 271-304.

Williams, J. P., Brown, L., Silverstein, A. K., \& deCani, J. S. (1994). An instructional program in comprehension of narrative themes for adolescents with learning disabilities. Learning Disabilities Quarterly, 17, 205-221.

Wolf, M. (1984). Naming, reading, and the dyslexias: A longitudinal overview. Annals of Dyslexia, 34, 87-136.

Wolf, M., Bally, H., \& Morris, R. (1986). Automaticity, retrieval processes, and reading: A longitudinal study in average and impaired readers. Child Development, 57, 988-1000.

Wolf, M., Bowers, P. G., \& Biddle, K. (2000). Naming-speed processes, timing, and reading: A conceptual review. Journal of Learning Disabilities, 33, 387- 407.

Wolf, M., Miller, L., \& Donnelly, K. (2000). Retrieval, automaticity, vocabulary elaboration, orthography (RAVE-O): A comprehensive, fluency-based reading intervention program. Journal of Learning Disabilities, 33, 375-386.

Woodcock, R. (1998). Woodcock Reading Mastery Tests - Revised. Circle Pines, MN: American Guidance Service.

Yuill, N., \& Oakhill, J. (1991). Children's problems in text comprehension. Cambridge, UK: Cambridge University Press. 